\title{
Bimbingan Penyuluhan Terhadap Bahaya Virus Covid-19 Dengan Perilaku Hidup Bersih dan Sehat (PHBS)
}

\author{
Noffiyanti \\ UIN Raden Intan Lampung, Bandar Lampung, Indonesia \\ noffiyanti@radenintan.ac.id \\ Priska Amanda Mauliddia \\ UIN Raden Intan Lampung, Bandar Lampung, Indonesia \\ priskaamandam@gmail.com
}

\begin{abstract}
Abstrak
Penelitian ini bertujuan untuk menyelidiki Bimbingan Penyuluhan Terhadap Bahaya Virus Covid-19 Dengan Perilaku Hidup Bersih dan Sehat (PHBS). Pada penelitian ini menggunakan pendekatan kulitatif deskriptif. Pendekatan ini dipilih karena ingin mengeksplorasi gambaran yang ada di lapangan terkait dengan pelaksanaan Bimbingan Penyuluhan Terhadap Bahaya Virus Covid-19 Dengan Perilaku Hidup Bersih dan Sehat (PHBS) dalam tatanan keluarga maupun masyarakat secara luas. Teknik pengumpulan data menggunakan observasi partisipatif, yakni peneliti terlibat langsung dengan masyarakat guna mengetahui kebiasaan masyarakat Datadata yang didapatkan dari observasi nantinya akan dikumpulkan dan dianalisis dengan menggunakan analisis struktural. Hasil penelitian menunjukkan bahwa munculnya wabah Covid-19 mendorong pentingnya untuk memberikan Edukasi terhadap masyarakat tentang Perilaku Hidup Bersih dan Sehat (PHBS). Selain itu, masyarakat perlu mengetahui dengan pasti penularan Virus Covid-19 dan Cara Pencegahan Covid-19 yaitu dengan tetap di rumah saja, dan wajib menggunakan masker jika keluar rumah dan usahakan agar tidak berkontak fisik kepada orang lain. Selalu mencuci tangan dan menerapkan PHBS. PHBS merupakan strategi yang tepat untuk mencegah penyebaran Covid-19. Masyarakat terus dihimbau untuk selalu meningkatkan Pola Hidup Bersih dan Sehat dalam upaya pencegahan penyebaran Covid-19. Karena perilaku masyarakat sangat berperan penting dalam penurunan angka penyebaran
\end{abstract}


Pandemi Covid-19 yang sangat efektif dan mudah dilakukan oleh semua lapisan masyarakat. Rekomendasi pemerintah terus menghimbau gerakan PHBS menjadi kunci pencegahan penyebaran wabah yang sudah menyebar luas di seluruh dunia. Melakukan Perilaku Hidup Bersih dan Sehat diharapkan untuk menghambat penyebaran Covid-19 sehingga kejadian tidak bertambah. Oleh karena itu sangatlah penting melakukan Pola Hidup Bersih dan Sehat, perlu diterapkan secara terus menerus sehingga dapat meningkatkan pengetahuan seluruh lapisan masyarakat untuk menerapkan PHBS dalam Kehidupan Sehari-hari.

Kata kunci: Masyarakat, Covid-19, Pola Hidup Bersih dan Sehat.

\begin{abstract}
Counseling Guidance on the Danger of the Covid-19 Virus with Clean and Healthy Living Behavior. This study aims to investigate the Covid-19 Covid-19 Counseling Guidance with Clean and Healthy Living Behavior (PHBS). In this study using a descriptive qualitative approach. This approach was chosen because it wanted to explore the existing picture in the field related to the implementation of Covid-19 Covid-19 Counseling with Clean and Healthy Behavior (PHBS) in the family and society at large. The technique of collecting data uses participatory observation, in which the researcher is directly involved with the community in order to find out the habits of the community. The data obtained from the observations will later be collected and analyzed using structural analysis. The results showed that the emergence of the Covid-19 outbreak encouraged the importance of providing education to the public about Clean and Healthy Living Behaviors (PHBS). In addition, the public needs to know for sure the transmission of the Covid-19 Virus and Covid-19 Prevention Methods, namely by staying at home, and must use a mask when leaving the house and try not to have physical contact with other people. Always wash your hands and apply PHBS. PHBS is the right strategy to prevent the spread of Covid-19. The public continues to be urged to always improve a Clean and Healthy Lifestyle in an effort to prevent the spread of Covid-19. Because people's behavior plays an important role in reducing the spread of the Covid-19 Pandemic which is very effective and easy for all levels of society to do. Government recommendations continue to call on the PHBS movement to be the key to preventing the spread of the epidemic that has spread widely throughout the world. Conducting a Clean and Healthy Life Behavior is expected to prevent the spread of Covid-19 so that incidents do not increase. Therefore it is very important to carry out a Clean and Healthy Lifestyle, it needs to be applied continuously so that it can
\end{abstract}


increase the knowledge of all levels of society to apply PHBS in everyday life.

Keywords: Society, Covid-19, Clean and Healthy Lifestyle

\section{A. Pendahuluan}

Dewasa ini manusia dikagetkan dengan mewabahnya virus Corona (Covid19) yang melanda hampir di seluruh belahan dunia. Virus Corona pertama ditemukan pada bulan Desember 2019 di Wuhan, Cina. Hingga saat ini Mei 2020 sudah menyebar di 216 negara dan menginfeksi lebih dari 5.8 juta penduduk di dunia termasuk Indonesia (Habiba et al., 2020). Covid-19 merupakan keuarga dari jenis virus corona yang mampu menyerang saluran pernapasan. Sehingga menyebabkan gangguan saluran pernapasan akut atau sering disebut dengan SARS. Virus jenis ini menjadi sangat mengkhawartikan dikarenakan tingkat penyebarannya yang sangat cepat. Beberapa gejala klinis yang menjadi indikasi terpaparnya Covid-19 yang terjadi pada seseorang, diantaranya yaitu : demam, batuk pilek, letih lesu, sakit tenggorokan dan gangguan pernapasan (Sulaeman \& Supriadi, 2020). Namun terdapat beberapa orang yang tidak menunjukkan gejala apapun, tetapi dinyatakan terpapar Virus Covid-19 ini. Sehingga perlu kewaspadaan dari masyarakat, yang dimulai dari diri sendiri. Salah satunya dengan selalu menjaga kesehatan tubuh dengan memberlakukan pola hidup bersih dan sehat.

Pola hidup bersih dan sehat atau yang sering disebut dengan PHBS dapat dikaitkan dengan perubahan pola perilaku yang ada pada diri seseorang dengan menerapkan kebiasaan untuk menjaga kebersihan dan kesehatan diri serta lingkungannya. Atau dengan kata lain PHBS merupakan suatu upaya yang dilakukan yang berkaitan dengan peningkatan pemahaman, sikap maupun perilaku dalam menerapkan, memelihara dan meningkatkan cara hidup sehat dalam tatanan terkecil sampai terluas dalam suatu kelompok masyarakat. Akan tetapi, perilaku PHBS di lingkungan masyarakat dewasa ini mengalami penurunan.

Hal tersebut dapat diamati di Kelurahan Way Dadi. Berdasarkan studi awal menunjukkan bahwa PHBS belum selayaknya menjadi kebiasaan yang dikembangkan masyarakat. khususnya pada kondisi krisis kesehatan yang diakibatkan oleh covid-19 seperti sekarang ini. Salah satunya dengan masih ditemukan banyaknya bentuk pengabaian protocol kesehatan sesuai dengan anjuran pemerintah. Hal tersebut yang melatar belakangi perlu adanya upaya lain yang mampu memberikan pemahaman kepada masyarakat untuk lebih mampu 
mengaplikasikan tidak hanya protocol kesehatan seperti yang di sarankan oleh pemerintah. Melainkan juga, pola kebiasaan yang nantinya akan dilakukan secara kontinyu sebagai bagian dari budaya kesehatan dalam masyarakat. salah satu upaya yang hendaknya dilakukan yakni bimbingan penyuluhan.

Bimbingan penyuluhan merupakan upaya yang dilakukan oleh pihak terkait (konselor) dalam memberikan edukasi kepada masyarakat. Melalui program yang dilakukan dalam kegiatan bimbingan konseling, diharapkan setiap anggota masyarakat, tidak hanya memahami pentingnya pola hidup bersih dan sehat (PHBS) melainkan juga mampu mengaplikasikannya dalam kehidupan sehari-hari. Bimbingan penyuluhan merupakan upaya yang cocok untuk memberikan edukasi kepada masyarakat. hal tersebut seperti halnya yang diungkapkan oleh Mirwan et al., (2020) dalam penelitiannya mengungkapkan bahwa, bimbingan penyuluhan merupakan metode yang sesuai guna memberikan pemahaman kepada masyarakat, karena mengandalkan kecakapan dalam berkomunikasi yang dioleh menjadi sebuah komunikasi persuasive ataupun dalam bentuk nasihat.

Selain itu, disampaikan juga bahwa seorang penyuluh, tidak hanya berkutat pada hal yang terkait dengan agama saja, melainkan juga sebagai pendaping masyarakat. Karena tujuan Penyuluhan jangka panjang yaitu membangun sebuah masyarakat berdasarkan cita-cita Islam, yang memenuhi beberapa prinsip minimal yang didalamnya, seperti prinsip-prinsip dasar Islam tentang keluarga, sosial kemasyarakatan, politik, maupun ekonomi (Bastomi, 2020). Sehingga seorang penyuluh juga mampu berperan dalam memberikan edukasi kepada masyarakat terkait semua hal yang termasuk dalam kemaslahatan umat. Hal senada diungkapkan oleh Jaya (2017), dalam penelitian nya diungkapkan bahwa seorang penyuluh hendaknya memberikan pendampingan kepada masyarakat dengan melibatkan berbagai pihak terkait dalam proses pelakasanaannya.

Berdasarkan kajian dari penelitian sebelumnya, maka bimbingan penyuluhan mempunyai posisi yang cukup penting dalam kehidupan bermasyarakat, khususnya dalam kegiatan pemutusan mata rantai penularan covid-19 ini. Dari jabaran penelitian sebelumnya, kajian penelitian yang penulis ajukan menunjukkan perbedaan yang nyata. Dikarenakan focus pada kajian penelitian yang disampaikan menitik beratkan pada kegiatan bimbingan penyuluhan yang dilakukan kepada masyarakat terkait dengan penerapan perilaku hidup bersih dan sehat (PHBS).

Berdasarkan uraian yang diungkapkan sebelumnya, maka dapat penelitian ini bertujuan untuk memberikan gambaran yang terkait dengan pengaplikasian 
bimbingan penyuluhan tentang bahaya covid-19 melalui program penerapan pola hidup bersih dan sehat (PHBS). Sehingga yang menjadi problem penelitian adalah bagaimana pengaplikasian bimbingan penyuluhan terkait dengan bahaya covid-19 melalui program pola hidup bersih dan sehat (PHBS) dalam masyarakat.

\section{B. Metode}

Pada penelitian ini menggunakan pendekatan kulitatif deskriptif. Pendekatan ini dipilih karena ingin mengeksplorasi gambaran yang ada di lapangan (Sugiyono, 2018) terkait dengan pelaksanaan bimbingan penyuluhan yang dilakukan guna memberikan edukasi bahaya covid-19 serta berbagai bentuk PHBS dalam tatanan keluarga maupun masyarakat secara luas. Teknik pengumpulan data menggunakan observasi partisipatif, yakni peneliti terlibat langsung dengan masyarakat guna mengetahui kebiasaan masyarakat serta efek yang ditimbulkan dari promosi kesehatan melalui bimbingan dan penyuluhan. Selain itu, dalam penelitian ini melibatkan masyarakat sebagai partisipasi aktif yang nantinya akan diamati secara langsung berbagai pola perilaku alamiah yang ada terkait dengan kesadaran kesehatan, serta sikap yang ditunjukkan sebagai bentuk pemahaman terkait dengan covid-19. Data-data yang didapatkan dari observasi nantinya akan dikumpulkan dan dianalisis dengan menggunakan analisis struktural.

\section{Pembahasan}

\section{Pengertian Bimbingan dan Penyuluhan}

Bimbingan secara etimologis merupakan terjemahan dari kata Guidance berasal dari kata kerja to Guide yang mempunyai arti menunjukkan, membimbing, menuntun ataupun membantu (Prayitno, 2013). Secara umum bimbingan dapat diartikan sebagai suatu bantuan atau tuntunan. Namun, meskipun demikian tidak berarti semua bantuan atau tuntutan adalah bimbingan. Bimbingan adalah bantuan yang diberikan oleh seseorang baik laki-laki maupun perempuan yang memiliki pribadi yang baik dan pendidikan yang memadai, kepada seseorang individu maupun kelompok dari setiap umur untuk membantunya mengembangkan aktivitas-aktivitas hidupnya sendiri mengembangkan arah pandangannya sendiri, membuat pilihan sendiri, dan memikul bebannya sendiri.

Bimbingan juga diartikan suatu proses bantuan yang diberikan pada seseorang dengan memperhatikan kemungkinan-kemungkinan dan kenyataan tentang adanya kesulitan yang dihadapinya dalam rangka perkembangannya yang optimal, sehingga dapat memahami diri, mengarahkan diri dan bertindak serta 
bersikap sesuai dengan tuntutan dan keadaan (Winkel \& Sri Hastuti, 2010). Miller berpendapat bimbingan adalah sebuah proses bantuan terhadap individu untuk mencapai pemahaman dan pengarahan diri yang dibutuhkan untuk melakukan penyesuaian diri secara maksimal kepada sekolah, keluarga serta masyarakat. Sementara itu ada juga yang memberikan difinisi bahwa bimbingan adalah bantuan yang diberikan kepada individu untuk mengatasi kesulitan-kesulitan di dalam kehidupannya supaya itu dapat mencapai kesejahteraan hidupnya atau dengan kata lain, bimbingan adalah bantuan yang diberikan seseorang dalam usaha memecahkan masalah-masalah yang dihadapinya. Dalam keterangan yang lain menyatakan bimbingan adalah suatu proses pemberian bantuan yang terus menerus dan sistematis dari pembimbing kepada orang yang dibimbing agar tercapai kemandirian dalam pemahaman diri, penerimaan diri dan pengarahan serta perwujudan diri dalam mencapai tingkat perkembangan yang optimal dan penyesuaian diri dengan lingkungan (Tohirin, 2013).

Sedangkan, Penyuluhan menurut bahasa berasal dari terjemahan bahasa inggris yaitu Counseling yang berarti pemberian nasehat, penyuluhan dan penerangan. Maksudnya adalah seseorang yang memberikan nasehat terhadap orang lain yang membutuhkan penanganan untuk memecahkan masalah-masalah yang sedang dihadapi. Penyuluhan dalam arti umum adalah ilmu sosial yang mempelajari sistem dan proses perubahan pada individu serta masyarakat agar dapat terwujud perubahan yang lebih baik sesuai dengan yang diharapkan. Penyuluhan adalah suatu proses pemberian bantuan baik kepada individu ataupun kelompok dengan mengunakan metode-metode psikologis agar individu atau kelompok dapat keluar dari masalah dengan kekuatan sendiri, baik secara preventif, kuratif, korektif maupun development (Tohirin, 2013). Penyuluhan menurut Arifin adalah hubungan timbal balik antara dua individu, dimana yang seorang (penyuluh) berusaha membantu yang lain (klien) untuk mencapai pengertian tentang dirinya sendiri dengan hubungannya dalam masalah yang dihadapi pada saat ini dan mungkin pada waktu yang akan datang (Zainal, 2009).

Berdasarkan pendapat para ahli di atas dapat diketahui penyuluhan adalah merupakan salah satu teknik dalam pelayanan bimbingan dimana proses pemberian bantuan itu berlangsung melalui wawancara dalam serangkaian pertemuan langsung dan tatap muka antara pembimbing dengan klien dengan tujuan agar klien mampu memperoleh pemahaman yang lebih baik terhadap dirinya untuk mengembangkan potensi yang dimilikinya kearah perkembangan yang optimal, sehingga ia dapat mencapai kebahagiaan pribadi dan kemanfaatan sosial dan mengerti terhadap masalah yang dihadapi pada saat itu dan mungkin pada waktu yang akan datang. 
Hal tersebut, bertujuan agar individu dapat membuat pilihan-pilihan, penyesuaian-penyesuaian dan dalam hubungannya dengan situasi-situasi tertentu. Dan didalam bimbingan terdapat beberapa fungsi, salah satunya adalah fungsi pencegahan, pencegahan didefinisikan sebagai upaya mempengaruhi dengan cara yang positif dan bijaksana yang dapat menimbulkan kesulitan atau kerugian sebelum kesulitan atau kerugian itu benar-benar terjadi. Ada suatu slogan yang berkembang dalam bidang kesehatan, yaitu mencegah lebih baik dari pada mengobati (Alif, Bhakti, 2020).

\section{Sikap Masyarakat Terhadap Covid-19}

Virus Covid-19 adalah penyakit yang menyerang sistem pernapasan pada manusia. Virus ini telah menginfeksi jutaan orang sehingga menyebabkan angka kematian yang tinggi bagi penderitannya di seluruh dunia, tidak terkecuali di Indonesia. Kasus Covid-19 di Indonesia sangat menggemparkan masyarakat dan menimbulkan ketakutan dari berbagai kalangan. Covid-19 merupakan penyakit yang disebabkan oleh Virus SARS CoV-2 dengan gejala umum gangguan saluran pernafasan akut baik ringan maupun berat yang meliputi : demam, batuk pilek, letih lesu, sakit tenggorokan dan gangguan pernapasan. Secara umum Penularan virus ini terjadi melalui droplet atau cairan tubuh yang terpercik pada sesorang atau benda-benda di sekitarnya yang berjarak 1-2 meter melalui batuk dan bersin.

Berdasarkan hasil penelitian yang telah dilakukan, masyarakat cenderung masih menyepelekan upaya pemutusan mata rantai penyebaran covid-19 ini. Hal tersebut dibuktikan dengan banyaknya temuan selama penelitian yang mengindikasikan sebagian dari anggota masyarakat belum sepenuhnya mematuhi protocol kesehatan yang di anjurkan oleh pemerintah; selain itu, kebiasaan masyarakat dalam penerapan hidup sehat dan bersih belum sepenuhnya diterapkan secara maksimal.

Hal tersebut ditunjang dengan adanya temuan berbagai tindakan dalam pelaksanaan kontak social maupun dalam praktik tata cara pelaksanaan kegiatan keseharian, masih cenderung mengabaikan hal-hal yang dianggap kecil, akan tetapi mempunyai pengaruh besar, diantaranya rutinitas cuci tangan yang sempurna.

Pengetahuan masyarakat sangat berpengaruh terhadap prilaku dalam melakukan pencegahan. Menurut Notoatmojo, perilaku merupakan suatu aktivitas seseorang yang bersangkutan dan mempunyai kapasitas yang sangat luas mencakup : berjalan, berbicara, bereaksi, dan berpakaian. Kunci pencegahan penularan virus ini dapat menerapkan prilaku hidup sehat seperti mencuci tangan, konsumsi makanan sehat, olah raga dan istirahat yang cukup serta tidak lupa juga untuk mematuhi protokol kesehatan (Rahmadeni, 2019). Kesadaran dari masing- 
masing individu, dapat berperan aktif dalam mencegah penyebaran Virus Covid19. Dengan menerapkan pola hidup sehat dan mematuhi protokol kesehatan merupakan langkah terbaik dalam pencegahan penyebaran virus ini, sehingga perlu ditanamkan kepada semua lapisan-lapisan masyarakat tentang pengetahuan hidup sehat dan pentingnya mematuhi protokol kesehatan dimasa pandemi saat ini.

Masyarakat terus dihimbau untuk meningkatkan perilaku hidup sehat dalam upaya pencegahan penyebaran Covid-19, karena perilaku masyarakat sangat berperan penting dalam penurunan angka penyebaran Covid-19. Dengan menerapkan pola hidup sehat merupakan salah satu starategi dalam pencegahan penyebaran Covid -19 yang sangat efektif dan mudah dilakukan oleh semua lapisan masyarakat. Rekomendasi pemerintah terus menghimbau gerakan PHBS menjadi kunci pencegahan penyebaran Covid-19 pada masa pandemi ini. Melakukan pencegahan dengan menerapkan pola hidup sehat dan mematuhi protokol kesehatan diharapkan penyebaran Covid-19 dapat dihambat sehingga kejadian tidak bertambah. Oleh karena pentingnya pola hidup sehat dan pentingnya mematuhi protokol kesehatan perlu dilakukan pemberian informasi secara terus menerus sehingga dapat meningkatkan pengetahuan seluruh masyarakat untuk menerapkan hidup sehat dalam kehidupan sehari-hari.

Upaya pencegahan yang dapat dilakukan adalah dengan melakukan berbagai kegiatan salah satunya penyuluhan untuk dapat memberikan data dan informasi yang ilmiah kepada seluruh masyrakat tetang Virus Covid-19 di Indonesia yang dapat dijangkau masyarakat. Pengetahuan sangat berpengaruh terhadap masyarakat yang menjadi sasaran dalam pemberian informasi yang edukatif dengan metode yang lebih inovatif. Cara pencegahan penyebaran Covid19 yang paling efektif adalah dengan memutus rantai penularan yang dikaitan dengan cara-cara penularan Covid-19. Penularan infeksi Covid-19 terutama terjadi melalui kontak fisik.

Pencegahan penularan virus ini dapat dicegah dengan menerapkan Pola Hidup Sehat dan mematuhi protokol kesehatan, seperti cuci tangan dengan baik dan benar, etika batuk, menjaga kesehatan dan sistem kekebalan tubuh, jaga jarak serta menggunakan masker ketika berpergian. Pengetahuan dan pemahaman masyarakat yang ilmiah, akurat dan dapat dipercaya dapat membantu untuk mudah melaksanakannya dalam menekan penyebaran Covid-19 di Indonesia. Atas dasar inilah perlu dilakuakan kegiatan pemberian informasi untuk meningkatkan pengetahuan masyarakat dalam menghadapi dan melewati pandemi Covid-19. 
Dengan mengadakan bimbingan penyuluhan terhadap virus Covid-19 dengan menerapkan pola hidup sehat dan mematuhi protokol kesehatan, dapat mencapai semua lapisan masyarakat dan dapat mempraktekkan pola hidup sehat dalam kehidupan sehari-hari dan menjadi contoh bagi masyarakat sekitar. Dalam hal ini perlu adanya bimbingan penyuluhan terkait pola hidup sehat dan pentingnya mematuhi protokol kesehatan, karena masih banyak masyarakat belum mengerti sehingga masih banyak masyarakat menganggap hal yang tidak penting. Tetapi masyarakat tidak perlu khawatir pada masa pandemi Virus Covid19 ini karena dengan penerapan Pola Hidup Sehat yang meliputi menjaga makanan yang bergizi, cukup istirahat, mampu meningkatkan sistem kekebalan tubuh dan dapat mengendalikan infeksi Covid-19. Proteksi diri dapat dilakukan dengan mematuhi protokol kesehatan menggunakan masker, selalu cuci tangan dengan bersih dan jaga pola hidup sehat dan bersih maka mampu mencegah virus masuk kedalam tubuh manusia.

\section{Perilaku Hidup Bersih dan Sehat (PHBS) Dikalangan Masyarakat}

Menciptakan hidup sehat sebenarnya sangatlah mudah serta murah, apabila dibandingkan dengan biaya yang harus dikeluarkan untuk pengobatan apabila mengalami gangguan kesehatan cukup mahal. Hidup sehat merupakan hal yang seharusnya diterapkan oleh setiap orang, mengingat manfaat yang ditimbulkan akan sangat banyak, mulai dari konsentrasi kerja, kesehatan dan kecerdasan anak sampai dengan keharmonisan keluarga (Nurhajati, 2015).

Program PHBS di Rumah Tangga merupakan upaya untuk memberdayakan anggota rumah tangga agar tahu, mau dan mampu mempraktikkan perilaku hidup bersih dan sehat serta berperan aktif dalam gerakan kesehatan di masyarakat. PHBS di Rumah Tangga dilakukan untuk mencapai Rumah Tangga berperilaku hidup bersih dan sehat. Perilaku hidup bersih dan sehat seseorang sangat berkaitan dengan peningkatkan kesehatan individu, keluarga, masyarakat dan lingkungannya. Menurut teori HL BLUM diketahui bahwa status kesehatan individu erat kaitanya dengan perilakunya, semakin baik perilaku yang berhubungan dengan kesehatan maka maka status kesehatanya akan semakin baik (Umaroh \& Heri, 2016)

Berdasarkan hasil Riskesdas 2013 menunjukkan bahwa proporsi nasional rumah tangga dengan PHBS baik adalah 32,3 persen, dengan proporsi tertinggi pada DKI Jakarta $(56,8 \%)$ dan terendah pada Papua $(16,4 \%)$. Terdapat 20 dari 33 provinsi yang masih memiliki rumah tangga PHBS baik di bawah proporsi nasional. Program pembinaan PHBS yang dicanangkan pemerintah sudah berjalan cukup lama, namun pada kenyataanya capaian keberhasilannya masih jauh dari 
harapan. PHBS merupakan salah satu indikator untuk menilai kinerja pemerintah daerah kabupaten/kota dibidang kesehatan, yaitu pencapaian 70\% rumah tangga sehat. Menurut Laporan Akuntanbilitas Kinerja Kementrian Kesehatan RI tahun 2014 adalah bahwa target rumah tangga ber-PBHS adalah 70\%. Dari yang ditargetkan pemerintah sebesar $70 \%$ tersebut provinsi Sulawesi Selatan capaiannya baru mencapai 35\% (Badan Penelitian dan Pengembangan Kesehatan Kementrian Kesehatan Republik Indonesia, 2013).

Pemberdayaan masyarakat harus dimulai dari rumah tangga atau keluarga, karena rumah tangga yang sehat merupakan aset atau modal pembangunan di masa depan yang perlu dijaga, ditingkatkan dan dilindungi kesehatannya. Beberapa anggota rumah tangga mempunyai masa rawan terkena penyakit menular dan penyakit tidak menular, oleh karena itu untuk mencegah penyakit tersebut, anggota rumah tangga perlu diberdayakan untuk melaksanakan PHBS (Nurhajati, 2015).

Beberapa penelitian mendpatkan bahwa ada hubungan antara PHBS Rumah tangga dengan kejadian penyakit seperti diare dan leptospirosis. Penelitian di Kecamatan Karangreja menyimpulkan bahwa aspek kesehatan lingkungan dalam PHBS seperti penggunaan air bersih, penggunaan jamban sehat, dan perilaku membuang sampah berhubungan dengan kejadian penyakit diare (Irawan, 2013). Penelitian yang dilakukan di Candisari Kota Semarang juga mendapatkan bahwa PHBS Rumah Tangga yaitu kondisi selokan, keberadaan tikus, keberadaan air menggenang, sarana pembuangan limbah, sarana pembuangan sampah berhubungan dengan kejadian leptospirosis (Auliya, 2014).

Perilaku Hidup Bersih dan Sehat adalah sekumpulan perilaku yang dipraktikkan atas dasar kesadaran sebagai hasil pembelajaran yang menjadikan seseorang, keluarga, kelompok atau masyarakat mampu menolong dirinya sendiri (mandiri) di bidang kesehatan dan berperan aktif dalam mewujudkan kesehatan masyarakat (Depkes RI, 2011). PHBS dapat dilakukan di berbagai tatanan yaitu di rumah tangga, di sekolah, di tempat kerja, di tempat umum, dan di institusi kesehatan.

PHBS tatanan rumah tangga adalah upaya untuk memberdayakan anggota rumah tangga agar tahu, mau dan mampu melaksananakan perilaku hidup bersih dan sehat serta berperan aktif dalam gerakan kesehatan di masyarakat. PHBS di rumah tangga dilakukan untuk mencapai rumah tangga sehat. Di rumah tangga, sasaran primer harus mempraktikkan perilaku yang dapat menciptakan rumah tangga ber-PHBS, yang mencakup persalinan ditolong oleh tenaga kesehatan, memberi bayi ASI eksklusif, menimbang balita setiap bulan, menggunakan air 
bersih, mencuci tangan dengan air bersih dan sabun, menggunakan jamban sehat, memberantas jentik nyamuk, makan buah dan sayur setiap hari, melakukan aktivitas fisik setiap hari, dan tidak merokok di dalam rumah (Permenkes Nomor 2269 Tahun 2011).

\section{Bimbingan Penyuluhan Terhadap Bahaya Virus Covid-19 Dengan Perilaku Hidup Bersih dan Sehat (PHBS)}

Memerangi Virus Covid-19 ini kuncinya adalah menjaga pola hidup sehat dan mematuhi protokol kesehatan, hal ini sangat sederhana namun sangat efektif untuk dilakukan. Salah satunya adalah membiasakan diri mencuci tangan dengan sabun atau hand sanitizer setiap selesai melakukan aktivitas. Selain membekali masyarakat dengan pengetahuan tentang Virus Covid-19, perlu juga diberikan pengetahuan tentang kunci penting untuk terhindar dari penularan Virus Covid-19 yaitu pengetahuan tentang pola hidup sehat. Pemberian materi tentang penerapan pola hidup sehat dan mematuhi protokol kesehatan akan membantu masyarakat terhindar dari Virus Covid-19 dan penyakit infeksius lainnya (Sulaeman \& Supriadi, 2020). Bimbingan penyuluhan terhadap virus Covid-19 juga akan meningkatkan kesadaran dan pengetahuan masyarakat akan pentingnya menjaga lingkungan dan diri agar tetap sehat. Lingkungan yang sehat akan sangat membantu masyarakat yang tinggal di dalamnya untuk merasa nyaman, tenang dan bahagia sehingga dapat menikmati hidup. Adapun tubuh yang sehat dapat diperoleh dengan mengkonsumsi makanan yang bersih dan sehat serta lengkap gizi. Tubuh yang sehat akan sangat sulit untuk diinfeksi oleh berbagai agen penyakit berbahaya seperti Covid-19 atau penyakit lainnya, karena tubuh yang sehat memiliki pertahanan (imunitas) yang kuat dan mudah melakukan penyebuhan sendiri.

Pentingnya perilaku hidup bersih dan sehat dalam menghadapi covid-19 ini didukung oleh Anhusadar dan Islamiyah (2021) dalam penelitiannya mengungkapkan bahwa pola hidup bersih dan sehat di gunakan sebagai bentuk promosi kesehatan sebagai bagian dari perubahan perilaku akan pemahaman kesehatan yang ada dimasyarakat yang senantiasa memberikan kontribusi yang besar dalam kehidupan bermasyarakat. Selain itu, disampaikan juga oleh Raksanagara dan Raksanagara (2015) mengungkapkan bahwa, pola hidup bersih dan sehat dapat digunakan sebagai bentuk preventif pada penularan berbagai penyakit yang disebabkan oleh lingkungan yang kurang bersih. Sehingga, perilaku hidup bersih dan sehat sangat dianjurkan dan dimulai dari lingkungan keluarga.

Berdasarkan kajian yang telah disampaikan bahwa, penelitian yang disampaikan jika dibandingkan dengan penelitian sebelumnya terdapat kelemahan 
dan keunggulan. Kelemahan dalam penelitian yang diajukan yakni belum mampu mengungkapkan efektifitas secara kuantitatif terkait dengan pelaksanaan pelayanan bimbingan penyuluhan yang dilakukan kepada masyarakat. sedangkan keunggulan dari penelitian yang disampaikan yakni menekankan pada promosi kesehatan yang diperlukan oleh masyarakat pada umumnya agar siap dalam menghadapi pandemi covid-19 dan juga era setelahnya. Sehingga, penelitian ini mempunyai kontribusi yang cukup relevan terhadap kondisi yang ada sekarang ini, dan juga masa mendatang. Yakni diantaranya terkait dengan edukasi pentingnya memahami, menjaga dan melestarikan upaya dalam meningkatkan kesadaran akan kebersihan dan kesehatan masyarakat, yang dimulai dari lingkup kecil yaitu diri sendiri dan keluarga.

\section{Simpulan}

Dengan dilaksanakannya Bimbingan Penyuluhan terhadap bahaya virus Covid-19, masyarakat dapat memahami dan mengetahui bagaimana menerapkan perilaku hidup bersih sehat dan pentingnya mematuhi protokol kesehatan untuk mencegah terjadinya penyebaran atau penularan Virus Covid-19 pada masa pandemi saat ini. Pemberian Bimbingan Penyuluhan Pentingnya Menjaga Physical Distancing terhadap Virus Covid-19 dengan menerapkan pola hidup sehat dan pentingnya mematuhi protokol kesehatan, masyarakat bisa mencontoh sekaligus melakukannya kepada diri sendiri ataupun keluarganya. Masyarakat perlu adanya bimbingan mengenai Virus Covid-19 pada masa pandemi ini guna memberikan informasi dan menambah pengetahuan bagi masyarakat, agar masyarakat bisa mengambil keputusan yang tepat dalam menjalani kehidupan sehari-hari di masa pandemi saat ini supaya terhindar dari Virus Covid-19. 


\section{DAFTAR PUSTAKA}

Alif, Bhakti, K. (2020). Edukasi Perilaku Hidup Bersih dan Sehat (PHBS) dalam Pencegahan Covid-19 Kepada Anak-Anak di Panti Asuhan. Pengabdian Magister Pendidikan IPA, 3, 69.

Auliya, Rizka. (2014). Hubungan Antara Strata PHBS Tatanan Rumah Tangga dan Sanitasi Rumah dengan Kejadian Leptospirosis. Unnes Journal of Public Health 3.3.

Anhusadar, L. O., \& Islamiyah. (2021). Penerapan Perilaku Hidup Bersih dan Sehat Anak Usia Dini di Tengah Pandemi Covid 19. Jurnal Obsesi : Jurnal Pendidikan Anak Usia Dini, 5(1), 463-475. https://doi.org/10.31004/obsesi.v5i1.555

Badan Penelitian dan Pengembangan Kesehatan Kementrian Kesehatan Republik Indonesia. (2013). Riset Kesehatan Dasar

Bastomi, H. (2020). Optimization Of Religious Extension Role In Covid-19 Pandemic. Journal of Advanced Guidance and Counseling, 1 No. 2, 157-179. https://doi.org/10.21580/jagc.2020.1.2.6032

Departemen Kesehatan RI, (2011). Panduan Sosialisasi Tatalaksana Diare Pada. Balita, Jakarta, Kementerian Kesehatan Republik Indonesia

Habiba, B., Mulyani, S., Nia, N. I., \& Nugroho, P. (2020). Konsep Layanan Responsif bagi Siswa yang Mengalami Kesulitan Belajar secara Daring Dimasa Pandemi Covid-19. Konseling Edukasi: Journal of Guidance and Counseling, 4 (2).

Irawan, Alfa Yosi. (2013). Hubungan Antara Aspek Kesehatan Lingkungan Dalam PHBS Rumah Tangga Dengan Kejadian Penyakit Diare Di Kecamatan Karangreja Tahun 2012. Unnes Journal of Public Health 2.4

Mirwan, Trinurmi, S., \& Syamsyidar. (2020). Metode Bimbingan dan Penyuluhan Islam dalam Meningkatkan Kesadaran Masyarakat. Jurnal Washyah, 1(2), 288-304.

Nurhajati, N. (2015). Perilaku Hidup Bersih dan Sehat (PHBS) Masyarakat Desa Samir dalam Meningkatkan Kesehatan Masyarakat.

Peraturan Menteri Kesehatan RI Nomor: 2269/Menkes/PER/XI/2011 Tentang Pedoman Pembinaan Perilaku Hidup. Bersih Dan Sehat.

Prayitno, E. A. (2013). Dasar-Dasar Bimbingan \& Konseling. PT. Rineka Cipta.

Rahmadeni. (2019). Penyuluhan Perilaku Hidup Bersih dan Sehat dan Pembagian 
Sembako pada Anak di Panti Asuhan Mahbbatul Haq Tanjung Uma Batam. Abdimas Saintika, 1, 141-144.

Raksanagara, A. S., \& Raksanagara, A. (2015). Perilaku Hidup Bersih dan Sehat Sebagai Determinan Kesehatan yang Penting pada Tatanan Rumah Tangga di Kota Bandung. JSK, 1(1), 30-34.

Revitalisasi Peran Penyuluh Agama Dalam Fungsinya Sebagai Konselor Dan Pendamping Masyarakat. (2017). KONSELING RELIGI: Jurnal Bimbingan Konseling Islam, Vol. 8, No.

Sugiyono. (2018). Metode Penelitian Kualitatif. Alfabeta.

Sulaeman \& Supriadi. (2020). Peningkatan Pengetahuan Masyarakat Desa Jelantik dalam Menghadapi Pademi Corona Virus Diseases-19 (Covid-19). Pengabdian \& Pembardayaan Kepada Masyarakat, 1, 12-17.

Tohirin. (2013). Bimbingan dan Konseling di Sekolah dan Madrasah. PT Raja Grafindo.

Umaroh, A. K., Heri, Y. H., Choiri. Gambaran Perilaku Hidup Bersih dan Sehat (PHBS) di Wilayah Kerja Puskesmas Bulu Kabupaten Sukoharjo. Jurnal Kesehatan. 2016; 1(1).

Winkel \& Sri Hastuti. (2010). Bimbingan dan Konseling di Institut Pendidikan. Media Abadi.

Zainal, A. (2009). Bimbingan Penyuluhan Islam. PT Raja Grafindo. 